\title{
Insights on Imparting Medical Education in Medieval India
}

\section{Mumtaz Alam*}

\begin{abstract}
The imparting of medical education in India since ancient to medieval times has been a theme of research among several historians like Mark Harrison, Deepak Kumar, Anil Kumar, Syed Ali Nadeem Rezavi, Irfan Habib and others, who had tried to highlight dissemination of medical knowledge, diseases, remedies and progress in medical practices. This article purports to give an overview of imparting of medical education in medieval India, highlight the importance of Ayurvedic physicians, Unani medical doctors hakims; role played by several Indian rulers in enhancing the medical education; teacher-student relationship in medical profession; two way traveling of physicians from Iran to India and vice-a-versa. This article is based on in-depth study of several primary Persian historical records, memoir and letters and simultaneously with several European travel records.
\end{abstract}

Key words: Medieval Medical Education, Hakims, Tibb, vaids, Unani Medicine

* Assistant Professor in History, Fiji National University, Fiji Islands 
The medical education in India can be traced from the ancient times when the knowledge was imparted and practiced by the vaidyas who enjoyed a responsible position in the society. Both Charaka and Susruta are widely known for having been good physicians and teachers who laid down certain principles for the men of medicine. Susruta sought certain qualities in a physician. According to both Charaka and Susruta a good physician must be a person who is well versed in the science of medicine and has attended to demonstration of surgery and medicine. Besides, a physician should practice the healing art, and is clean, courageous, light handed fully equipped with supplies of medicine, surgical instruments and appliance. Together with this, a physician also must be intelligent, well read, and is a name of ready resources and is further endorsed with all moral virtues ${ }^{1}$.

The Ayurvedic physicians or vaidya formed a recognized craft group not distinct as a caste but often following the profession of their fathers and forefathers. ${ }^{2}$ They distributed the medicines to their patient, which were prepared by them. The relationship between the vaidyas and their patients was totally religious. They were well versed in religious matters. They also served as teachers and trained their pupils in the art of healing. ${ }^{3}$ People from the various castes were engaged in this noble profession. For example it is reported from Orissa that a village vaidya, who was a member of the warrior class and a holder of a small plot of land, have cured many people of their diseases. This indicates that people belonging to different caste and class also practiced as vaidya. ${ }^{4}$

The students (sishya) would assist their teachers in dealing with the patients. They would also prepare medicine under the guidance of their guru ${ }^{5}$.The advent of the Muslims in India brought a tremendous change not only in the

1 SushrutaSamhita: Sutrasthanam, An English Translation, of the Based On Original Sanskrit Text, KavirajKunja Lal Bhishagratna, KashiGhose Lane, Calcutta, Vol. I, I907, pp.30-31; available at http://www.archive.org/details/englishtranslati01susruoft.

2 A.L. Basham, "The practice of Medicine in Ancient and Medieval India", in Charles Leslie (ed.),Asian Medical Systems: A comparative Study, University of California Press, Berkeley, Los Angeles, London, 1976, p.23

3 Girindra Mukhopadhyaya, History of Indian Medicine, Calcutta, University Press of Calcutta, 1926, Vol II. p. 21

4 F.G. Bailey, Caste and Economic Frontier, Manchester, England, Manchester University Press, 1957; cf. Charles Leslie (ed.), Asian Medical Systems, op. cit.,p.38.

5 For the system containing in modern Bengal see Brahmanade Gupta, Indigenous Medicine in Nineteenth and Twentieth Century Bengal, in Charles Leslie (ed.),Asian Medical Systems,op. cit., p. 368 
social and political sphere but also in the domain of education and learning. The Muslim rulers patronized the education alike both the Hindu and Muslim subjects. ${ }^{6}$

The first centre of Unani medicine in the whole of South Asia was set up at Lahore in or around 1160 A.D. under the patronage of the Ghaznavide rulers. ${ }^{7}$ The court of the early Turkish rulers of the Delhi Sultanate became a bee-hive of literary men, poets' philosophers and scientists who gave great impetus to the literary life of the day.

Abu-al-Rayhan Muhammad ibn Ahmad al Biruni gives us an insight into the rapid progress that Arabic and Persian literature were then making in unveiling the rich store of knowledge imbedded in both Sanskrit and Greek literature. Ancient mathematics, astronomy, astrology, philosophy, medicine and pharmacology were favourite subjects of study with Muslim scholars. The translations of Indian works, including a large portion of narrative literature was being made into Arabic and Persian by these energetic and inquisitive scholars. ${ }^{8}$

Mohammad Qasim Hindu Shah or Firishta informs us that under the Khalji rule:

"Places, mosques, universities, baths, mausoleum, forts and all kinds of public and private buildings seemed to rise as if by magic. Neither did there in age, appear such a concourse of learned men from all parts. Forty five doctors, skilled in the sciences were professors in the universities"9.

Those who taught Unani medicine were known as hakim and the teachers of the Ayurveda were the vaidyas. Like vaidyas the hakims also had a reputed position in the society. Quite a number of hakims had specialties in the medical treatment side by side both systems of medicine seem to have collaborated because they learn from each other. There is hardly any

6 See for example NarendraNath Law, Promotion of Learning in India with a forwarded by H. Beveridge, Longmans, Green \& Co, London, Calcutta, 1916, pp. xiv-xivi.

7 See TazimuddinSiddiqi, "Unani Medicine in India during the Delhi Sultanate", Studies in History of Medicine, Vol. 2, no.3, 1978, pp.183-89

8 See Preface Edward C. Sachan (ed.),Alberuni's India: An Account of the Religion, Philosophy, Literature, Geography, Chronology, Astronomy, Custom, Laws and Astronomy of India about A.D. 1030, with notes and Indices, S. Chand \& Co., New Delhi, First Indian reprint, 1964. Cf Narendra Nath Law,Promotion of Learning in India, op. cit., pp.13-14.

9 Abul Qasim Firishta, Tarikh-i Firishta, eng.tr.The History of the Rise of the Mahometan Power in India, London, 1829, Vol.I, p.35 
evidence to suggest that there was animosity between vaidya and hakim in their field. ${ }^{10}$ It suggests they may have cordial relation among them.

Firoz Shah Tughlaq was himself skilled in the Science of medicine, logic, astronomy and mathematics. He used to attend on patients afflicted with any extraordinary disease in order to acquaint him with its symptoms ${ }^{11}$. Another contemporary work of Abdul Abbas Ahmed mentions that at the royal court at Delhi, there were a thousand poets skilled in one of the three languages such as Arabic, Persian, or Indian and twelve hundred physicians. ${ }^{12}$ Regarding cure centres or hospitals also mentions that in Delhi alone there were thousands of colleges and about seventy hospitals called Daru-sh-shifa or house of cure. 13

The Mughal emperors also extended the educational activities of the Sultanate period. They were uniformly interested in the development of medical sciences and in the organization of hospitals and clinics.Unani Medicine received liberal encouragement from the Mughal rulers. According to Abul Fazl, there were 29 physicians in the state service ${ }^{14}$ (both Hindus and Muslims). Their actual number would have exceeded thousands when the whole country was considered. According to Abul Fazl, Akbar had directed the instruction of tibb with the other sciences in the school curriculum. In one the passages of the Ain Abul Fazl informs:

"...this method of teaching be adopted, a boy will learn in a month, or even in a day, what it took others years to understand, so much so that people will get quite astonished. Every boy ought to read books on morals, arithmetic, the notation peculiar to arithmetic, agriculture, mensuration, geometry, astronomy, physiognomy, household matters, the rules of government, tibb, logic the tabii, riyazi, and ilahi, sciences and history; all of which may be gradually acquired" 15 .

10 A.L. Basham, "The practice of Medicine in Ancient and Medieval India", op. cit., pp.39-40

$11 \quad$ N. N. Law, op.cit. p.44

12 Shahabuddin Abdul Abbas Ahmad, Masalikul Absar fi Mamalikul Ansar in Elliot and Dowson, The History of Indian as told by its Historian,Vol. iii, LPP, New Delhi, 2001, p.579.

13 Ibid.,p.576

14 Abul Fazl, Ain i Akbari, Translated into English by H. Blochmann, edited by D.C. Phillot, Vol. I, Low Price Edition, Delhi, reprint, 2008, pp.611-13

15 Ibid.,p.289 
Probably the teaching of tibb under the Mughals was mainly tutor oriented. ${ }^{16}$ That is why in India, there were not many specialized colleges for medical sciences as we find in the contemporary Aleppo, Egypt or Iran. ${ }^{17}$ The author of Maasir-i Rahimi of clearly mentions the medical educational system prevalent in the madarsas. Two prominent hakims of this period named Hakim Shams and Hakim Muin run a madarsa at Thatta and also taught medicine there. ${ }^{18}$ Similar information is corroborated by Shah Nawaz Khan in Maasirul Umara in which he discusses about a Gujrati physician who had his own makhtab in which he divulged education. ${ }^{19}$ In these institutions, the teachers were not only responsible for the medical education and training but also looked after the general welfare of the students. While these students were residing with their teachers, the physician's clinics and the homes were turn into the great centres for learning. The medical education was always provided along with religious instructions. ${ }^{20}$

During the reign of Aurangzeb, Hakim Mir Muhammad Hashim better known as Hakim Hashim flourished. He opened a well-known madarsa at Ahmadabad. ${ }^{21}$ Similar madarsa was run by Hakim Alimuddin Wazir at his native palace Chiniot in Punjab. ${ }^{22}$ The Tibb was taught through dawakhanas (dispensaries) and sharbatkhanas (syrup houses) often run through state munificence. ${ }^{23}$

The skill of the students of colleges which existed in India were not however inferior to any. Father Monserrate mentions a school of medical science at Sirhind which was very famous and whose products were widely practicing

16 See amongst others, Abdul Jalil, "The Evolution and Development of Graeco-Arab Medical Education", Studies in History of Medicine, Vol. II, No, 3, September, 1978, p.195.

17 See S.A.N. Rezavi, "Physicians as Professionals in Medieval India", in Deepak Kumar (ed.), Disease and Medicine in India: A Historical Overview, Indian History Congress, Tulika Publication, New Delhi, 2001, p. 41.

18 Abdul BaqiNahawandi, Maasir-i Rahimi, ed. Hadayat Hussain, Vol. II, Calcutta, 1931, p. 274

19 Shah Nawaz Khan, MaasirulUmara, edited by MaulviAbdur Rahim, Vol. III, Calcutta, 1888-90, pp.280-81

20 S. L .Bhatia, A History of Medicine with Special Reference to the Orient, Office of the Medical Council of India, New Delhi, 1977,p.126

21 Abdul Hamid Lahori, Padshahnama, edited by Kabiruddin Ahmad and Abdul Rahman, Vol. I, Part II, Calcutta, 1867, pp.345-46

22 Maasir-ulUmara, op. cit., Vol. III, p.936

23 Abdul Jalil, "The Evolution and Development of Graeco-Arab Medical Education", Studies in History of Medicine, Vol. II, No, 3, September, 1978, p.125 
all over the empire. ${ }^{24}$ The actual needs of the physicians in the Mughal Empire were not fulfilled by these madarsas and there was a great scope for people getting educated outside the country.

A considerable number of physicians of Mughal period acquired the knowledge from various academics in places like Lihijan (Gilan), Mashhad, Ishfahan, Iran, Shiraz and Arab came to India for their better fortune. ${ }^{25}$ But some existing evidences indicate that contrary to the above flow of scholars from outside some Indian scholars also went to Iran for training and education in tibb. Ahmad Thattavi went to Iran from Sindh and studies in Shiraz ${ }^{26}$ and Muhammad Akbar Arzani, the court physician of Aurangzeb and native of Delhi went to Iran for further studied in tibb. ${ }^{27}$

A large number of physicians came to India from outside as well. Hakim Mir Muhammad Mehdi Ardistani an Iranian physician came to India and joined Aurangzeb's court. ${ }^{28}$ Hakim Abdur Razzaq Mashrab also came to India from Ishfahan during the days of Emperor Aurangzeb. ${ }^{29}$ Hakim Abdur Razzaq

24 The Commentary of Father Monserrate, translated by J.S. Hoyland, annotated by S. N. Benerjee, Calcutta, 1922, p.103

25 For Example see, Abdul Hayy, Nuzhat-ulKhawatir, ed by Sharifuddin Ahmad, Vol. VI, Hyderabad, 1962-79, p.357, 364; Hakim Abdul Hameed, Hakim Abdul Hameed, Medicine during Mughal Period, in Interaction between India and Central Asia: Science and Technology in Medieval Times, Vol. II, Medicine, Technology, Arts and Crafts, Architecture and Music, INSA, New Delhi, 1990, p.39; Kausar Chand Puri, Atibba-i Ahd-i Mughaliya, Hamdard Academy, Karachi, 1955, p.207.; Abdul Hamid Lahori, Padshahnama, Vol. I, Part, II, pp.345-46; C. Storey, op.cit, II, p.276; A. Rahman,op.cit. p.75; Mirza Muhammad Saqi and Munshi Muhammad Kazim, AlamgirNama, Matballahi, Agra, 1873, p.399; Shahnawaz Khan, Maasir-ulUmara, Vol. I,Lahore, 1968, p. 594; Muhammad Bukhtawar Khan, Mira'tul Alam, edited by Sajida Alavi, Lahore, 1979, Vol. I, p.297; Abdul Hamid Lahori, Padshahnama, Asiatic Society of Bengal, Calcutta, 1868, Vol.I, p.441; MaulanaGhulam Ali Azad Bilgrami, Maasir al-Karam, Book-2, p.201

26 Shahnawaz Khan, Maasir-ulUmara, Vol. III, p.263

27 S.A.N. Rezavi, Physicians as Professionals in Medieval India, in Deepak Kumar (ed.), Disease and Medicine in India: A Historical Overview, Indian History Congress, Tulika Publication, New Delhi, 2001, p. 42

28 Mirza Muhammad Saqi and Munshi Muhammad Kazim, AlamgirNama, Matballahi, Agra, 1873, p.399; Shahnawaz Khan, Maasir-ul-Umara, Vol. I, Lahore, 1968, p. 594; Abdul Hayy, Nuzhat-ulKhawatir, ed. by Sharifuddin Ahmad, Vol. VI, Hyderabad, 1962-79, p.357; See also, Muhammad Bukhtawar Khan, Mira'tul Alam, edited by Sajida Alavi, Lahore, 1979, Vol. I, p.297

29 Abdul Hamid Lahori, Badshahnama, Asiatic Society of Bengal, Calcutta, 1868, Vol. I, p.441; see also, A.K. Bagchi, Medicine in Medieval India: $11^{\text {th }}$ to $18^{\text {th }}$ Centuries, Konark Publication, New Delhi, 1997, p.104 
Ishfahani distinguished himself in medicine. He came to India during the reign of Alamgir and settled in Bareilly. ${ }^{30}$ Hakim Sheikh Hussain Shirazi belonged to Arabia but came to be known as Shirazi. He came to India during the reign of Aurangzeb and got attached as a physician to the court of Muhammad Azam Shah son of Aurangzeb. ${ }^{31}$ Famous physician Muhammad Hashim bin Hadi bin Muzaffaruddin Alavi Khan Shirazi following his education in Shiraz came to in 1700A.D. Emperor Aurangzeb who bestowed on him the robe of honour and gifts and deputed him to the service of his son, Muhammad Azam. ${ }^{32}$ Hakim Hashim acquired knowledge in Iran but flourished in India during Aurangzeb reign. ${ }^{33}$ Hakim Sikander bin Hakim Ismail Yunani came from Istanbul to India towards the end of Mohammad Shah's reign. ${ }^{34}$

As far as madarsas in the Mughal Empire imparting education in tibb is concerned, the largest information comes from the reign of Aurangzeb. During his reign several such madrasas were established. Special mention may be made of Firangi maha lmadarsa at Lucknow which emerged as one of the famous and advanced madarsas of the eighteenth century India. ${ }^{35}$

Francois Bernier mentions that the Firangi Mahal was a Dutch building at Lucknow and Aurangzeb allotted it for a madarsa. ${ }^{36}$ In the late eighteenth century the Firangi Mahal became a major institution where students arrived for further medical apprenticeship to the clinics of the hakim of Oudh. The

Abdul Hayy, Nuzhat-ulKhawatir, op .cit., Vol.6, p.147

MaulanaGhulam Ali Azad Bilgrami, Maathir al-Karam, op. Cit., Book-2, p.201

Abdul Hayy, Nuzhat al-Khawatir, vol.6, p.364; Hakim Abdul Hameed, Medicine during Mughal Period, In Interaction between India and Central Asia: Science and Technology in Medieval Times, Vol. II, Medicine, Technology, Arts and Crafts, Architecture and Music, INSA, New Delhi, 1990, p.39; Kausar Chand Puri, Atibba-i Ahd-i Mughaliya, Hamdard Academy, Karachi, 1955, p.207

33 Abdul Hamid Lahori, Padshahnama, Vol. I, Part, II, pp.345-46

34 See Charles Ambrose Storey, Persian Literature A Bibliographical Survey, Vol. II, Part 2, E. Medicine, The Royal Asiatic Society of Great Britain and Ireland, Luzac and Co. Ltd, London, 1971, p.276; See also, Alvi, M.A. \&Rahman, A. et al, Science and Technology in Medieval India: A Bibliography of Source Materials in Sanskrit, Arabic Persian, INSA, New Delhi, 1982, p.75

35 Jigar Muhammad, “ Mughal Support to Madarsa Education (1556-1748)", Paper presented at National Seminar, April 5 ${ }^{\text {th }}-7^{\text {th }} 2005$, Centre of Advanced Study Department of History, Aligarh Muslim University, Aligarh.(unpublished)

36 Francois Bernier, Travels in the Mogul Empire, AD 1656-1668, translated from French by Irving Brock, revised and annotated by A. Constable, London, 1891; This version, revised and annotated by V.A. Smith, London, 1914, 1916, rep., New Delhi, 1968, p.292. 
dars-i-nizamiya or curriculum of the Firangi Mahal was prepared with the consideration to fulfil the basic requirement of the tibbi education. Most young hakims at Lucknow first trained at the madarsa, where they received basic instruction in both rational sciences (muaqulat) and religion (manqulat) before graduating to attend indebt lectures and course in medicine. ${ }^{37}$ Until the mid-eighteenth century the students of Unani medicine were taught in madarsas, individual clinics and homes. ${ }^{38}$

After the collapse of Mughal Empire Unani medicine came under the patronage of regional elites or wealthy/ eminent people like zamindars, talluqdars and the nawabs. ${ }^{39}$ From the mid eighteenth century onward their position of physicians was further strengthened on account of the discoveries of new elements and techniques in the realm of the medical sciences. ${ }^{40}$

The method of teaching in Unani system of medicine in Mughal period was mainly teacher oriented and the students studied some books of medicine and were attached to the clinics of some celebrated physicians. The students spent most of their time with their teacher, sat by his side when he examined the patients, watched the diagnosis listened to the report given by the patients the question put to him and recorded prescription as dictated. During off hours or at night the senior tabib taught his students. The students also engaged in preparation of medicines. The clinics of reputed physicians served as school or tutorials where education in Unani medicine both in theory and practical were given. There were also concepts of physician's family in Mughal period. These physicians used to teach Tibb to their sons at their homes and made them well-versed in the medical profession, the father or the grandfather acted as the teacher or enter for their some and grandiose. ${ }^{41}$

37 Francis Robinson, The Ulema of Farangi Mahal and Islamic Culture in South Asia, Delhi, 2001, p.213

38 Seema Alavi, "A National Medicine in Colonial India: The Muslim physicians and the Takmil-ul Tibb College at Lucknow", Lectured held at Max Mueller Bhavan, New Delhi, 04.04.2012. (I am Thank full to Prof. S.A.N. Rezavi, Deputy Coordinator, Centre of Advanced Study, Department of History, Aligarh Muslim University, Aligarh for providing the article copy to me.)

39 Ibid.

40 Narendra Kumar Dutt, Origin and Growth of Caste in India, (2 Vols combined in single book) Vol. II, Calcutta, pp.252-6

41 A.H. Israili, 'Education of Unani Medicine During Mughal Period', Studies in History of Medicine, Vol. IV, No.3, September, 1980, pp. 179-180 
Overall, one can conclude that arrival of physicians increased in India during the Medieval period, this happened due to several factors such as the patronization given by rulers, more curiosity towards medical education, teacher-student relationship became much more stronger to disseminate medical education, need of the society of medical practitioners arose tremendously, providing of medical education along with religious instructions and finally, coming of several European physicians to India. The movement of physicians was two-ways, and not restrain to only coming to India while it happened other way round also, where several Indian physicians went outside India for medical practice. Besides the movement of physicians, vaidyas and hakims shared cordial relationships and it enhance the medical skills for treatment of patients. After the dismissal of Mughal Empire, the patronage of medical practitioners continued by several regional zamindars, talluqdars and the nawabs; this was further boosted by new discoveries in medical sciences during this period

\section{Conclusion}

Finally, one can conclude that in ancient period we have scanty information about how teaching was imparted on the subject. Medicine was practiced and local level institutions were maintained by individual vaidyas. Medical education received some impetus during the medieval period. The economic prosperity of Mughal India provided ample opportunity to the hakims to raise their position. They also enjoyed a respectable status in the society and were well paid for their practice. Mughal Emperors also took personal interest in the development of medical sciences and hence established a number of centres and institutions (madarsas/matabs) for the same purpose. 
Jhss, Vol. 7, No. 1 , January to June, 2016

\section{References}

A.H. Israili, 'Education of Unani Medicine During Mughal Period', Studies in History of Medicine, Vol. IV, No.3, September, 1980, pp. 179-180.

A.L. Basham, "The practice of Medicine in Ancient and Medieval India", in Charles Leslie (ed.),Asian Medical Systems: A comparative Study, University of California Press, Berkeley, Los Angeles, London, 1976

Abdul Baqi Nahawandi, Maasir-i Rahimi, ed. Hadayat Hussain, Vol. II, Calcutta, 1931

Abdul Hamid Lahori, Padshahnama, edited by Kabiruddin Ahmad and Abdul Rahman, Vol. I, Part II, Calcutta, 1867

Abdul Jalil, "The Evolution and Development of Graeco-Arab Medical Education", Studies in History of Medicine, Vol. II, No, 3, September, 1978

Abul Fazl, Ain i Akbari, Translated into English by H. Blochmann, edited by D.C. Phillot, Vol. I, Low Price Edition, Delhi, reprint, 2008

Abul Qasim Firishta, Tarikh-i Firishta, eng.tr. The History of the Rise of the Mahometan Power in India, Vol. I, London, 1829

F.G. Bailey, Caste and Economic Frontier, Manchester, England, Manchester University Press, 1957; cf. Charles Leslie (ed.), Asian Medical Systems, op. cit.p.38.

Francis Robinson, The Ulema of Farangi Mahal and Islamic Culture in South Asia, Delhi, 2001

Francois Bernier, Travels in the Mogul Empire, AD 1656-1668, translated from French by Irving Brock, revised and annotated by A. Constable, London, 1891; This version, revised and annotated by V.A. Smith, London, 1914, 1916, rep., New Delhi, 1968 
Girindra Mukhopadhyaya, History of Indian Medicine, Calcutta, University Press of Calcutta, 1926, Vol II.

Jigar Muhammad, “ Mughal Support to Madarsa Education (1556-1748)", Paper presented at National Seminar, April $5^{\text {th }}-7^{\text {th }} 2005$, Centre of Advanced Study Department of History, Aligarh Muslim University, Aligarh.(unpublished)

Mirza Muhammad Saqi and Munshi Muhammad Kazim, Alamgir Nama, Matballahi, Agra, 1873

Narendra Kumar Dutt, Origin and Growth of Caste in India, (2 Vols combined in single book) Vol. II, Calcutta

S. L .Bhatia, A History of Medicine with Special Reference to the Orient, Office of the Medical Council of India, New Delhi, 1977

S.A.N. Rezavi, Physicians as Professionals in Medieval India, in Deepak Kumar (ed.), Disease and Medicine in India: A Historical Overview, Indian History Congress, Tulika Publication, New Delhi, 2001

Seema Alavi, "A National Medicine in Colonial India: The Muslim physicians and the Takmil-ul Tibb College at Lucknow", Lectured held at Max Mueller Bhavan, New Delhi, 04.04.2012

Shah Nawaz Khan, Maasirul Umara, edited by MaulviAbdur Rahim, Vol. III, Calcutta, 1888-90

Shahabuddin Abdul Abbas Ahmad, Masalikul Absar fi Mamalikul Ansar in Elliot and Dowson, The History of Indian as told by its Historian, Vol. iii, LPP, New Delhi, 2001

Sushruta Samhita: Sutrasthanam, an English Translation, of the Based On Original Sanskrit Text, KavirajKunja Lal Bhishagratna, KashiGhose Lane, 
Jhss, Vol. 7, No. 1, January to June, 2016

Calcutta, Vol. I, 1907, pp.30-31, available at http://www.archive.org/details Lenglishtranslati01susruoft.

The Commentary of Father Monserrate, translated by J.S. Hoyland, annotated by S. N. Benerjee, Calcutta, 1922 